\title{
The Design and Practice on Literature Appreciation Course of Foreign Language Profession Combined with the Cultivation of Creativity -- Taking Appreciation of French Literature as an Example
}

Lin Yao

School of Foreign Languages, Guilin Institute of Tourism, Guilin 541006, Guangxi Province, China

Funding: This article is the 2018 education and teaching reform project of Guilin School of Tourism: Research on the construction of foreign language teaching courses for the cultivation of innovation and entrepreneurship--Taking Guilin Institute of Tourism as an example (project number: 2018XJJGB039).

\begin{abstract}
In the curriculum arrangement of foreign language majors, the literature appreciation is an important professional course. The common course design of this course focuses on the teaching of knowledge points and the training of language ability, which cannot effectively cultivate students' innovative ability. Therefore, this article integrates the cultivation of creativity and literary appreciation ability, and combines the case sharing of classroom teaching practice to explore the mode of foreign literature appreciation curriculum that can stimulate students' innovative awareness and cultivate students' innovative ability.
\end{abstract}

Key words: Creativity training; Foreign language major; Literary appreciation course; Course design

Publication date: December, 2020

Publication online: 31 December, 2020

"Corresponding author: Lin Yao, 738306017@ qq.com

\section{Introduction}

In May 2016, the Outline of the National Innovationdriven Development Strategy issued by the Central Committee of the Communist Party of China and the State Council proposed: "Innovation has become the first driving force for development." According to the French Professional Teaching Guideline for General Colleges and Universities Undergraduate (2020 revision), the requirements knowledge and ability of talent training: French majors should "master French literature knowledge and have the ability to appreciate literature." (Foreign Language and Literature Teaching Guideline for General University Undergraduate, Part 2, page 61). The courses related to French literature have therefore become professional courses in the training program for French majors. However, teachers can easily form a teaching model that "teaching mainly disseminate the language points and students memorize them" when designing a course. Apart from learning and memorizing relevant knowledge, students can neither think actively and independently nor have the opportunity to learn with innovative thinking.

Therefore, this article will start from the perspective of curriculum design, taking the course, Appreciation of French Literature, as an example. Combined with teaching practice, we explore how to enable students to acquire literary knowledge and language ability while achieving the development of innovation. 
2 The common modes of course design for appreciation of French literature

\subsection{The Common teaching materials and classification}

\subsubsection{General textbooks}

We take History of French Literature and Guide to French Literature: From the Middle Ages to the 20th Century as examples. These textbooks are mainly based on knowledge points in the framework, supplemented by reading and appreciation of the original text.

\subsubsection{Selected reading textbooks}

Selected Works of French Literature, Masterpiece of French Literature, etc. This type of textbook is mainly for reading and appreciation of the original text, supplemented by the teaching of knowledge points.

\subsection{Teaching method}

Teaching focuses on "French" and "literature", namely language ability training and establishment of knowledge structure in the field of literature; The goal is not "appreciation", that is, active thinking combined with teaching content, so as to produce its own unique learning results and learning experience.

\subsection{Teaching content}

Colleges and universities that focus on the cultivation of academic talents will choose general textbooks for teaching, which lays a good foundation for students to pursue higher education degrees; colleges and universities that focus on the cultivation of applied talents will choose optional textbooks for lectures and lectures on literature. It will provide students with more language learning materials while learning.

\subsection{Evaluation method}

Traditional examination is the most commonly used method, but such an assessment can hardly avoid students' cramming for tests. It fundamentally hinders students' willingness to think actively in this course, thereby losing the awareness of innovation.

\section{Curriculum design concept that integrates innovation ability cultivation and literature appreciation}

First of all, curriculum design is inseparable from curriculum positioning and curriculum goals. The analysis of the academic situation of French majors shows that at the undergraduate level, most of the French majors at the beginning of the study focus on language knowledge, and they are still unable to think effectively in French, and thus cannot effectively participate in more profound discussion in the classroom. Appreciation of French Literature course, as the core course of French professional literature, is different from the courses that cultivate and train language ability. It focuses on guiding and training students' ability to "appreciate" French literature. Therefore, the design concept of this course is based on a certain language ability from the famous French literature, combined with the teaching design of the online and offline classroom. That said, students can learn the knowledge points and read and appreciate the selected literature. At the same time, it gives full play to subjective initiative to conduct learning behavior led by innovative thinking. Students can improve their French through reading skill, while cultivating innovative appreciation skills. Eventually they form a good reading habit, laying a good foundation for future French employment and lifelong learning.

\section{Course design of appreciation of French literature}

\subsection{Selection of textbooks}

General textbooks are used. Teachers select representative writers based on age, genre, etc., and start teaching around their background, personal life, and representatives.

\subsection{Teaching methods}

Teaching methods: Teaching materials + multimedia audio-visual file playback + online and offline communication on the network platform + classroom discussion + classroom assignments.

\subsection{Curriculum design combined with teaching links}

\subsubsection{Online test before class}

Through the network platform test link, all students answer the questions online.

\subsubsection{The author's brief introduction and life anecdotes}

Through the flipped classroom-style classroom tasks, students can summarize, summarize, comment 
and supplement by teachers. The main language is French, with Chinese as a supplement.

\subsubsection{Introduction to masterpieces and reading of selected texts}

The teacher teaches, the teaching language is mainly French, and Chinese is the supplementary.

\subsubsection{Classroom tasks (class voting, discussion, quizzes, etc.)}

Teacher guidance, student participation, Chinese as the main language, French as a supplement.

\subsubsection{Classroom feedback}

The survey link is published through the online platform, and students complete it in class.

\subsection{Curriculum assessment method: "student's question + teacher's question"}

It means that students make self-proposed questions in groups to form practice questions for stage learning content. The questions that students have given will account for $60 \%$ of the score in the final exam. Therefore, the passing rate of the final exam can be guaranteed for students who have participated in the preparation of questions and answered the questions seriously; at the same time, teachers do not need to adopt methods such as "key knowledge points" and "scope of exam" to improve the quality of students' review. On the one hand, students can be able to review the knowledge while learning it at the same time. On the other hand, it also stimulates the enthusiasm of students to learn independently, and further consolidates classroom knowledge through questioning.

\section{Cases of classroom teaching practice}

Course content: French Renaissance prose masterMontaigne (Michel de Montaigne)

Classroom activity design:

(1) Displaying the results of the online test before class, as shown in the figure 1 below:

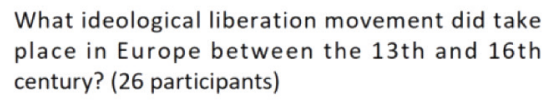

What ideological liberation movement did take place in Europe between the 13th and 16th century? (26 participants)

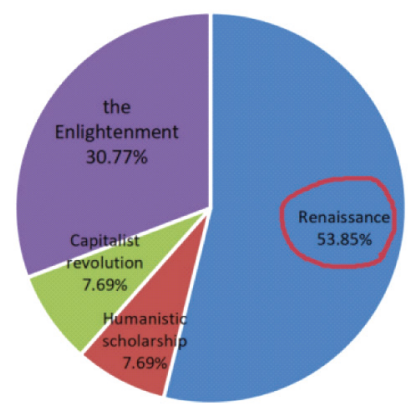

What's your favoriate literary genres? (26 participants)

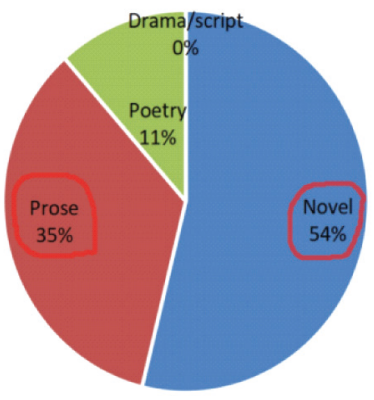

Figure 1. Results of online tests

(2) According to the analysis of the results of the pre-class test, the topic of this lesson is introduced. Through a video display of Montaigne's life and work introduction, the teacher arranged the first task of this class: according to the information of the videoclip and the content of the teaching material, students should write at least 3 descriptions of Montaigne in French. Each group make a presentation of the assignments. After the presentation, the teacher make comments on their work.

After this section, Montaigne's life, masterpieces and other knowledge points have been summarized by the students themselves. In order to test the learning effect of students, teachers assign a class quiz. Students send their answers to the discussion group, and teachers make comments.

(3) Class discussion with the theme "Chicken Soup 
for the Soul We Have Read". First of all, each student sends a favorite philosophical sentence in the course discussion group, either in Chinese or French. Then, the teacher share the part of Montaigne's quotations (French version) on PPT for reading and learning, comparing and discussing the shared philosophical sentences with students. Teacher encourages students to express their opinions and share their personal understanding.

(4) Setting up voting for "Your 3 favorite Montaigne Quotations", and students vote online.

(5) Assignment

a. Composition: Choose one of the three sentences with the highest votes, and write an afterthought in French around it.

b. Questions: Combining the background of Renaissance and humanism, from the content of Essay Collection, why is Montaigne called an outstanding humanist of the Renaissance? Send your opinions in Chinese to the course discussion group.

(6) Classroom feedback: After learning this lesson, what do you want to say? Some students' feedback is as follows:

"Montaigne is simply the originator of chicken soup, do you have it!"

"Actually, Montaigne is a lot like me. We are people who think a lot, but I'm too lazy to write them all down, otherwise I'm also a master..."

"After learning this lesson, I feel that the soul chicken soup that is forwarded on the Internet is weak. I wrote it hundreds of years ago. I feel like I understand a cool knowledge!"

"If the teacher can dismiss get out of class earlier, I want to go to the library to borrow an "Essay Collection" to see!"

\section{Conclusion}

The cultivation of innovative ability is inseparable from the development of innovative consciousness, and the development of it lies in learning with initiative and active thinking. Literature appreciation courses for foreign language majors not only have the characteristics of complicated knowledge points and a lot of content to memorize, but also have greater teaching difficulties due to their language factors. On the one hand, teachers must ensure the transmission of relevant knowledge while conducting language skills training; on the other hand, they must create conditions to improve students' learning enthusiasm and encourage students to think actively. Therefore, when designing the curriculum, teachers take the cultivation of innovative ability as one of the teaching goals, and design classroom content around the development of innovative consciousness. That way, it can not only enable students to learn important professional knowledge, but also give full play to their individuality and initiative in the learning process. Students will get a deeper learning experience, and form a more complete appreciation ability and personal quality.

\section{References}

[1] Wang YQ. 2018. Innovation-driven development strategy and countermeasures for cultivating innovation ability of foreign language talents in the new era $[\mathrm{J}]$. Contemporary Foreign Language Research, Issue 06, 2018: 81-91+105.

[2] Chen ZY. French Literature History [M]. Beijing: Foreign Language Teaching and Research Press, 1989.

[3] $\mathrm{Xu} \mathrm{ZH.} \mathrm{A} \mathrm{Guide} \mathrm{to} \mathrm{French} \mathrm{Literature:} \mathrm{From} \mathrm{the} \mathrm{Middle}$ Ages to the 20th Century [M]. Shanghai: Shanghai Foreign Language Education Press, 2006.

[4] Zhang F. Selected Works of French Literature [M]. Beijing: Foreign Language Teaching and Research Press, 2000.

[5] (French) Edited by Pluokan et al., Qian Peixin, translated by Chen Wei. Great French literature [M]. Shanghai: Shanghai Translation Publishing House, 2002. 